\title{
Ultrastructural analysis of uninstrumented root canal areas following various irrigation regimens
}

\author{
Radomir Barac ${ }^{1}$, Jelena Popović1, Slavoljub Živkovićn ${ }^{2}$ Aleksandar Mitić ${ }^{1}$, Marija Nikolić1, \\ Jovanka Gašić \\ 'Department of Dental Diseases and Endodontics, Dental Clinic, School of Medicine, University of Nišs, Nišs, Serbia; \\ 2Department of Restorative Odontology and Endodontics, School of Dental Medicine, University of Belgrade, Belgrade, \\ Serbia
}

\begin{abstract}
SUMMARY
Introduction During endodontic treatment smaller or larger areas of root canal wall remain non-instrumented. This can affect prognosis of endodontic treatment as some bacteria may be left behind. The purpose of this study was to evaluate the morphology of non-instrumented areas of the root canal wall using scanning-electron-microscopy (SEM) after completed instrumentation and various irrigation regiments.

Materials and Methods Eighteen single-rooted extracted teeth were divided into the six groups. One tooth in each group represented a control sample. In all samples only one half of the canal was instrumented using ISO 40 hand files. Control samples were subjected to an irrigation protocols without instrumentation. Irrigants used were physiological saline, $3 \%$ sodium hypochlorite and $15 \%$ of ethylene-diamine-tetra-acetate. Irrigation protocol included using each of these irrigants alone, or a combination of $\mathrm{NaOCl}$ and $\mathrm{EDTA}$, as well as their combination with final irrigation using $\mathrm{NaOCl}$ or chlorhexidine. Then after, roots were sectioned longitudinally and prepared for SEM.

Results Saline irrigation left pulpal debris on uninstrumented areas of the canal wall. Irrigation with $3 \% \mathrm{NaOCl}$ left behind canal wall with different forms of calcospherites. However, after EDTA irrigation dentin appeared as an undulating surface with open tubules without a smear layer. The combination of $\mathrm{NaOCl}$ and EDTA showed remnants of calcospherites and open slightly widened dentinal tubules. Final irrigation with $\mathrm{NaOCl}$ on the uninstrumented areas showed enlarged dentinal tubules along with dentinal erosion, while after final irrigation with $\mathrm{CHX}$ clean dentin and open dentinal tubules without smear layer were noted.

Conclusion From the morphological point of view, the most favorable effect of irrigation on both uninstrumented and uninstrumented canal walls was achieved after irrigation with $\mathrm{NaOCl}$ and EDTA or $\mathrm{NaOCl}$, EDTA and chlorhexidine as the final irrigant.
\end{abstract}

Keywords: root canal instrumentation; uninstrumented root canal areas; root canal irigation; SEM

\section{INTRODUCTION}

One of the basic preconditions for successful endodontic treatment is adequate instrumentation of the root canal. However, satisfactory instrumentation and irrigation is difficult to achieve due to the very specific and complex root canal morphology, as well as limited effect of instruments [1]. Morphological variations of the root canal system and inability of endodontic instruments to reach all parts of root canal wall make cleaning of complete root canal practically impossible $[1,2]$. Micro-computerized tomography has confirmed that some areas of root canal walls remain untouched after instrumentation [3-6]. These areas may contain bacteria and compromise endodontic treatment [7]. In addition, the presence of smear layer and debris as a result of instrumentation is significant clinical problem [2, 8]. This layer often contains bacteria and blocks dentinal tubules, which significantly decrease the effect of used irrigant affecting the quality of obturation and the outcome of endodontic treatment $[8,9]$.
Due to limited effectiveness of endodontic instruments in root canal cleaning, it is necessary to use appropriate chemical agents during and after instrumentation. Their role is to eliminate and reduce any remaining microorganisms as well as remove smear layer [8-10]. Even though there is no general consensus about removing smear layer immediately before obturation, most endodontists agree that if it is not removed, it could disintegrate and lead to microleakage due to the low quality of the bond strength between the sealer and root canal walls $[9,10]$.

The aim of this study was to use a SEM analysis to evaluate the morphology of uninstrumented areas of the root canal walls following mechanical instrumentation and application of various irrigation regimens.

\section{MATERIALS AND METHODS}

The material used in this research included 18 freshly extracted intact human maxillary single-rooted teeth without 
any visible damage (root caries, cracks, internal or external resorption, etc.). According to the irrigation regimens, all teeth were divided into six groups, with one tooth in each group representing a control specimen. The teeth samples were kept for eight hours in $0.5 \% \mathrm{NaOCl}$ solution to facilitate removal of organic debris. After rinsing teeth under running water, they were immersed in saline solution and refrigerated until the beginning of the experiment.

Prior to canal instrumentation, using a diamond disc, longitudinal grooves were created on the facial and lingual surfaces of the root, without penetrating it, in order to facilitate the fracture. The crowns were amputated and discarded, while the remaining debris was removed using running water. Following pulp extirpation, one tooth from each group (two control samples) underwent different irrigation regimens only without previous instrumentation. All root canals were checked for patency and working length was determined by shortening the distance to the anatomical foramen by $1 \mathrm{~mm}$. The apex was sealed with a pink wax piece.

The root canals of experimental teeth were instrumented using the step back technique to the instrument size 40 (NiTi files I-FLEX, IMD, USA). Only one half of each root canal, either the facial or the lingual half, was particularly marked and instrumented [11]. During the instrumenta- tion, care was taken that endodontic instruments did not come in contact with the oposing side of the canal wall that represented the "uninstrumented" half. The control sample from each group was used for comparison of uninstrumented areas of the canal with the uninstrumented main root canal following identical irrigation regimens. The amount of the irrigant used for each irrigation regimen was identical and carefully controlled, and the total time of chemomechanical preparation was $10 \mathrm{~min}$.

The following irrigation regimens were used: (I) saline; (II) 3\% sodium hypochlorite (NaOCl-Parcan,Septodont); (III) 15\% Ethylene diaminetetraacetic acid (EDTA - Largal Ultra, Septodont); (IV) combination of 3\% $\mathrm{NaOCl}+15 \%$ EDTA; (V) combination of $3 \% \mathrm{NaOCl}+15 \%$ EDTA and $3 \% \mathrm{NaOCl}$ as the final irrigant; (VI) combination of $3 \%$ $\mathrm{NaOCl}+15 \%$ EDTA and 2\% chlorhexidine (R4, Septodont) as the final irrigant (Table 1).

Applying mild pressure and using a spatula, the samples were fractured in half (so that a total of 36 samples were obtained) and placed in open Petri dishes to dry at the room temperature. After 24 hours, they were attached to cylindrical tooth carriers using a fixing agent (Dotite paint xc 12 Carbon JEOL, Tokyo, Japan), gold sputtered (using a JFC 1100E Ion Sputter JEOL) and analyzed using scanning electron microscopy (SEM, JEOL-JSM-5300).

Table 1. Irrigants and irrigation regimens of the experimental and control samples

Tabela 1. Irigacioni rastvori i protokol irigacije eksperimentalnih i kontrolnih uzoraka

\begin{tabular}{|c|c|c|c|}
\hline $\begin{array}{l}\text { Groups } \\
\text { Grupe }\end{array}$ & $\begin{array}{l}\text { Irrigants } \\
\text { Irigacioni rastvori }\end{array}$ & $\begin{array}{l}\text { Irrigation regimen of the experimental samples } \\
\text { (uninstrumented areas in uninstrumented canals)* } \\
\text { Irigacioni protocol eksperimentalnih uzoraka } \\
\text { (neinstrumentisane površine u instrumentisanim kanalima)* }\end{array}$ & $\begin{array}{l}\text { Irrigation regimen of the control samples } \\
\text { (uninstrumented canals)* } \\
\text { Irigacioni protocol kontrolnih uzoraka } \\
\text { (neinstrumentisani kanali)* }\end{array}$ \\
\hline 1 & Saline solution & $\begin{array}{l}\text { Irrigation using } 3 \mathrm{ml} \text { saline solution after pulp extirpation and } \\
\text { after each endodontic instrument } \\
\text { Irigacija sa } 3 \mathrm{ml} \text { fiziološkog rastvora posle ekstirpacije pulpe i } \\
\text { posle svakog endodontskog instrumenta }\end{array}$ & $\begin{array}{l}\text { Irrigation using } 3 \mathrm{ml} \text { saline solution following pulp } \\
\text { extirpation } \\
\text { Irigacija sa } 3 \mathrm{ml} \text { fiziološkog rastvora posle ekstirpacije } \\
\text { pulpe }\end{array}$ \\
\hline II & $\begin{array}{l}3 \% \mathrm{NaOCl} \\
\text { (Parcan, Septodont) }\end{array}$ & $\begin{array}{l}\text { Irrigation using } 3 \mathrm{ml} \mathrm{NaOCl} \text { following pulp extirpation and after } \\
\text { each endodontic instrument } \\
\text { Irigacija sa } 3 \mathrm{ml} \mathrm{NaOCl} \text { posle ekstirpacije pulpe i posle svakog } \\
\text { endodontskog instrumenta }\end{array}$ & $\begin{array}{l}\text { Irrigation using } 3 \mathrm{ml} \mathrm{NaOCl} \text { following pulp } \\
\text { extirpation } \\
\text { Irigacija sa } 3 \mathrm{ml} \mathrm{NaOCl} \text { posle ekstirpacije pulpe }\end{array}$ \\
\hline III & $\begin{array}{l}15 \% \text { EDTA } \\
\text { (Largal Ultra, } \\
\text { Septodont) }\end{array}$ & $\begin{array}{l}\text { Irrigation using } 3 \mathrm{ml} \text { saline solution following pulp extirpation } \\
\text { and after each endodontic instrument, final irrigation with } 3 \mathrm{ml} \\
\text { EDTA for } 60 \text { seconds } \\
\text { Irigacija sa } 3 \mathrm{ml} \text { fiziološkog rastvora posle ekstirpacije pulpe i } \\
\text { posle svakog endodontskog instrumenta; završno ispiranje sa } 3 \\
\text { ml EDTA u trajanju od } 60 \text { sekundi }\end{array}$ & $\begin{array}{l}\text { Irrigation using } 3 \mathrm{ml} \text { saline solution following pulp } \\
\text { extirpation, final irrigation using } 3 \mathrm{ml} \text { EDTA for } 60 \\
\text { seconds } \\
\text { Irigacija sa } 3 \mathrm{ml} \text { fiziološki rastvora posle ekstirpacije } \\
\text { pulpe; završno ispiranje sa } 3 \mathrm{ml} \text { EDTA u trajanju od } \\
60 \text { sekundi }\end{array}$ \\
\hline IV & $\begin{array}{l}3 \% \mathrm{NaOCl} \\
\text { (Parcan, Septodont) } \\
+15 \% \text { EDTA } \\
\text { (Largal Ultra, } \\
\text { Septodont) }\end{array}$ & $\begin{array}{l}\text { Irrigation using } 3 \mathrm{ml} \mathrm{NaOCl} \text { following pulp extirpation and after } \\
\text { each endodontic instrument; final irrigation using } 3 \mathrm{ml} \text { EDTA for } \\
60 \text { seconds } \\
\text { Irigacija sa } 3 \mathrm{ml} \mathrm{NaOCl} \text { posle ekstirpacije pulpe i posle svakog } \\
\text { endodontskog instrumenta; završno ispiranje sa } 3 \mathrm{ml} \mathrm{EDTA} \mathrm{u} \\
\text { trajanju od } 60 \text { sekundi }\end{array}$ & $\begin{array}{l}\text { Irrigation using } 3 \mathrm{ml} \mathrm{NaOCl} \text { following pulp } \\
\text { extirpation; final irrigation using } 3 \mathrm{ml} \text { EDTA } \\
\text { for } 60 \text { seconds } \\
\text { Irigacija sa } 3 \mathrm{ml} \mathrm{NaOCl} \text { posle ekstirpacije pulpe; } \\
\text { završno ispiranje sa } 3 \mathrm{ml} \text { EDTA u trajanju } \\
\text { od } 60 \text { sekundi }\end{array}$ \\
\hline V & $\begin{array}{l}3 \% \mathrm{NaOCl}+15 \% \\
\mathrm{EDTA} \text { and } 3 \% \\
\mathrm{NaOCl} \text { as the } \\
\text { final irrigant / kao } \\
\text { završni irigans }\end{array}$ & $\begin{array}{l}\text { Irrigation using } 3 \mathrm{ml} \mathrm{NaOCl} \text { following pulp extirpation and after } \\
\text { each endodontic instrument; flushing using } 3 \mathrm{ml} \text { EDTA for } 60 \\
\text { seconds, final irrigation using } 3 \mathrm{ml} \mathrm{NaOCl} \text { for } 3 \mathrm{~min} \text {. } \\
\text { Irigacija sa } 3 \mathrm{ml} \mathrm{NaOCl} \text { posle ekstirpacije pulpe i posle svakog } \\
\text { endodontskog instrumenta; ispiranje sa } 3 \mathrm{ml} \text { EDTA u trajanju od } \\
60 \text { sekundi, završno ispiranje sa } 3 \mathrm{ml} \mathrm{NaOCl} \text { u trajanju od } 3 \mathrm{~min} \text {. }\end{array}$ & $\begin{array}{l}\text { Irrigation using } 3 \mathrm{ml} \mathrm{NaOCl} \text { following pulp } \\
\text { extirpation; flushing using } 3 \mathrm{ml} \text { EDTA for } 60 \text { seconds, } \\
\text { final irrigation using } 3 \mathrm{ml} \mathrm{NaOCl} \text { for } 3 \text { min. } \\
\text { Irigacija sa } 3 \mathrm{ml} \mathrm{NaOCl} \text { posle ekstirpacije pulpe; } \\
\text { ispiranje sa } 3 \mathrm{ml} \text { EDTA u trajanju od } 60 \text { sekundi, } \\
\text { završno ispiranje sa } 3 \mathrm{ml} \mathrm{NaOCl} \mathrm{u} \mathrm{trajanju} \mathrm{od} 3 \mathrm{~min} \text {. }\end{array}$ \\
\hline VI & $\begin{array}{l}3 \% \mathrm{NaOCl}+15 \% \\
\text { EDTA and } 2 \% \\
\text { chlorhexidine } \\
\text { (R4, Septodont) as } \\
\text { the final irrigant / } \\
\text { kao završni irigans }\end{array}$ & $\begin{array}{l}\text { Irrigation using } 3 \mathrm{ml} \mathrm{NaOCl} \text { following pulp extirpation and each } \\
\text { endodontic instrument; flushing using } 3 \mathrm{ml} \text { EDTA for a period of } \\
60 \text { seconds, final irrigation using } 3 \mathrm{ml} \mathrm{CHX} \mathrm{for} 3 \mathrm{~min} \text {. } \\
\text { Irigacija sa } 3 \mathrm{ml} \mathrm{NaOCl} \text { posle ekstirpacije pulpe i posle svakog } \\
\text { endodontskog instrumenta; ispiranje sa } 3 \mathrm{ml} \text { EDTA u trajanju od } \\
60 \text { sekundi, završno ispiranje sa } 3 \mathrm{ml} \mathrm{CHX} \mathrm{u} \mathrm{trajanju} \mathrm{od} 3 \mathrm{~min} \text {. }\end{array}$ & $\begin{array}{l}\text { Irrigation using } 3 \mathrm{ml} \mathrm{NaOCl} \text { following pulp } \\
\text { extirpation; flushing using } 3 \mathrm{ml} \text { EDTA for } 60 \text { seconds, } \\
\text { final irrigation using } 3 \mathrm{ml} \mathrm{CHX} \mathrm{for} 3 \text { min. } \\
\text { Irigacija sa } 3 \mathrm{ml} \mathrm{NaOCl} \text { posle ekstirpacije pulpe; } \\
\text { ispiranje sa } 3 \mathrm{ml} \text { EDTA u trajanju od } 60 \text { sekundi, } \\
\text { završno ispiranje sa } 3 \mathrm{ml} \mathrm{CHX} \mathrm{u} \mathrm{trajanju} \mathrm{od} 3 \mathrm{~min} \text {. }\end{array}$ \\
\hline
\end{tabular}

*At the end of all the irrigation regimens, as well as after irrigation with each tested irrigant, sterile water was used [11] in the amount of $3 \mathrm{ml}$, and canal was dried with sterile paper points prior to the use of the following instrument/irrigant.

${ }^{*}$ Kod svih irigacionih protokola je na kraju, kao i posle irigacije sa svakim testiranim irigansom, korišćena sterilna voda [11] u količini od $3 \mathrm{ml}$, a kanal je sušen papirnatim poenima pre korišćenja sledećeg instrumenta/irigansa. 
Table 2. SEM analysis of uninstrumented and instrumented areas in the root canal after different irrigation protocols

Tabela 2. SEM opis neinstrumentisanih i instrumentisanih površina u kanalu korena posle različitih irigacionih protokola

\begin{tabular}{|c|c|c|c|}
\hline $\begin{array}{l}\text { Groups } \\
\text { Grupe }\end{array}$ & $\begin{array}{l}\text { Irrigants } \\
\text { Irigacioni rastvori }\end{array}$ & $\begin{array}{l}\text { Uninstrumented areas in uninstrumented canals } \\
\text { Neinstrumentisane površine } u \text { instrumentisanim kanalima }\end{array}$ & $\begin{array}{l}\text { Instrumented canals } \\
\text { Instrumentisani kanali }\end{array}$ \\
\hline 1 & $\begin{array}{l}\text { Saline solution } \\
\text { Fiziološki rastvor }\end{array}$ & $\begin{array}{l}\text { Amorphous layer of residual pulpal components found, along } \\
\text { with predentin and pulpal debris, tubules barely visible } \\
\text { Prisutan amorfni sloj zaostalih komponenata pulpe, } \\
\text { predentin i pulpni debris, kanalići se jedva uočavaju }\end{array}$ & $\begin{array}{l}\text { Smear layer and dentin debris, tubules not visible at all. } \\
\text { Razmazni sloj i dentinski debris, kanalići se uopšte ne } \\
\text { uočavaju }\end{array}$ \\
\hline II & $\mathrm{NaOCl}$ & $\begin{array}{l}\text { Absence of predentin and pulpal debris (pulpal } \\
\text { remnants), presence of dome-shaped and ridge-shaped } \\
\text { calcospherites, noted orifices of the tubules, rough surface } \\
\text { of calcospherites. } \\
\text { Odsutan predentin i pulpni debris (pulpni ostaci), prisutni } \\
\text { kupolasti i grebenasti kalcisferiti, uočavaju se otvori kanalića, } \\
\text { površina kalcisferita gruba }\end{array}$ & 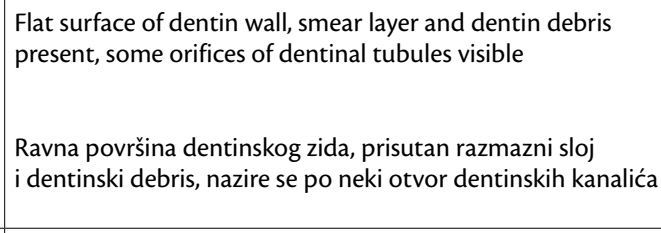 \\
\hline III & EDTA & $\begin{array}{l}\text { There are no calcospherites, pulpal debris was found, dentin } \\
\text { present as an undulating surface, open tubules } \\
\text { Ne uočavaju se kalcisferiti, nađeni delovi pulpnog debrisa, } \\
\text { talasasta površina dentinskog zida, otvoreni tubuli }\end{array}$ & $\begin{array}{l}\text { Flat surface of the dentin wall, removed smear layer, debris } \\
\text { present } \\
\text { Ravna površina dentinskog zida, uklonjen razmazni sloj, } \\
\text { prisutan debris }\end{array}$ \\
\hline IV & $\mathrm{NaOCl}+\mathrm{EDTA}$ & $\begin{array}{l}\text { Reduced calcospherites with smooth surface. No predentin } \\
\text { and pulpal debris, open tubules, slightly wider, clearly visible. } \\
\text { Smanjeni kalcisferiti sa glatkom površinom. Odsutan } \\
\text { predentin i pulpni ostaci, kanalići otvoreni, blago prošireni, } \\
\text { jasno uočljivi }\end{array}$ & $\begin{array}{l}\text { Flat surface of dentin, removed smear layer and dentin } \\
\text { debris, tubules wide open } \\
\text { Ravna površina dentinskog zida, uklonjen razmazni sloj i } \\
\text { dentinski debris, kanalići široko otvoreni }\end{array}$ \\
\hline V & $\begin{array}{l}\mathrm{NaOCl}+\mathrm{EDTA}+ \\
\mathrm{NaOCl}\end{array}$ & $\begin{array}{l}\text { Greater reduction of calcospherites in comparison to } \\
\text { previous irrigation regimen }(\mathrm{V}) \text {. No predentin and pulpal } \\
\text { debris. Tubules wide open, significantly enlarged, excessive } \\
\text { erosion of intertubular dentin } \\
\text { Veća redukcija kalcisferita u odnosu na prethodni } \\
\text { irigacioni protokol }(\mathrm{V}) \text {. Odsutni predentin i pulpni ostaci. } \\
\text { Kanalići široko otvoreni, znatno uvećani, izrazita erozija } \\
\text { intertubularnog dentina }\end{array}$ & 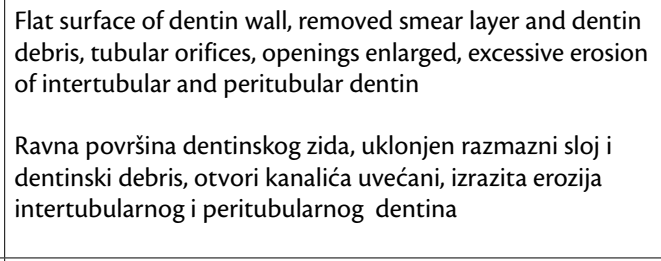 \\
\hline VI & $\begin{array}{l}\mathrm{NaOCl}+\mathrm{EDTA}+ \\
\mathrm{CHX}\end{array}$ & $\begin{array}{l}\text { Calcospherites reduction. Absence of predentin and pulpal } \\
\text { remnants, open tubules clearly visible, intertubular dentin } \\
\text { preserved. No difference compared to irrigation regimen IV } \\
\text { Redukcija kalcisferita. Odsutni predentin i ostaci pulpe, } \\
\text { kanalići otvoreni, jasno uočljivi intertubularni dentin očuvan. } \\
\text { Nije uočena razlika u odnosu na irigacioni protokol IV }\end{array}$ & $\begin{array}{l}\text { Flat surface of dentin wall, removed smear layer and dentin } \\
\text { debris, open dentinal tubules, intertubular dentin preserved } \\
\text { Ravna površina dentinskog zida sa uklonjenim razmaznim } \\
\text { slojem i dentinskim debrisom, otvoreni dentinski kanalići, } \\
\text { intertubularni dentin očuvan }\end{array}$ \\
\hline
\end{tabular}

\section{RESULTS}

After irrigation with saline pulpal debris covering dentin of uninstrumented areas of the canal was noticed. Irrigation with $3 \% \mathrm{NaOCl}$ left behind dentin with different forms of calcospherites. When EDTA was used alone for irrigation dentin was present as an undulating surface and open tubules without a smear layer were visible. Combination of $\mathrm{NaOCl}$ and EDTA for irrigation left remnants of calcospherites and open and slightly widened dentinal tubules. If $\mathrm{NaOCl}$ was used as the final irrigant (after $\mathrm{NaOCl}$ and EDTA) enlarged dentinal tubules were noted along with dentinal erosion, while if the final irrigant was CHX, clean dentin and open dentinal tubules without smear layer were noted.

SEM findings on uninstrumented and instrumented areas are shown in Table 2 and Figures 1-7. Wall morphology of uninstrumented areas in instrumented root canals did not show any differences compared to the morphology of uninstrumented canals (control samples) following all irrigation regimens.

\section{DISCUSSION}

The aim of this study was to analyze the morphology of uninstrumented areas of the root canal walls after canal instrumentation using SEM. Several studies used microcomputerized tomography to determine the presence of uninstrumented surfaces in the main root canal by calculating the area that remains intact after instrumentation (canal volume before and after instrumentation, distance between canal surface before and after instrumentation in $\mu \mathrm{m}$, the size of a specific area, the width of the canal, taper, etc.) [3-6]. On the other hand, SEM analysis allows visualization of root canal walls, their cleanliness, dentinal tubules covered with smear layer, as well as complete dentin morphology at ultrastructural level [13-15].

In the current study the control samples included uninstrumented canals after performed irrigation regimens. That way it was possible to compare the morphology of uninstrumented canals with uninstrumented surfaces of instrumented canals. According to Peters et al. after biomechanical instrumentation, both hand or rotary, approximately $35 \%$ of the canal wall remains untouched by the instruments [16]. In addition, other studies have also confirmed the presence of uninstrumented surfaces, especially in the apical third of the root canal, where any irregularities on canal walls (grooves and depressions) prevent contact between the wall and instrument $[17,18]$. Endodonic instruments are mostly designed to fit into the conical root configuration, which leaves untreated regions in oval and flat canals [16]. Beside complex canal morphology [19], limitation of instrumentation techniques 


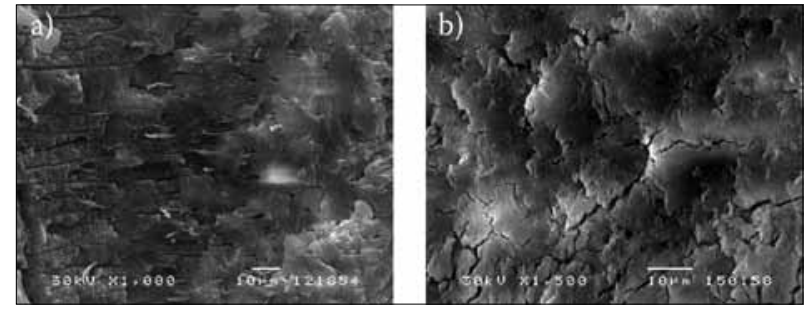

Figure 1. Saline solution. a) uninstrumented area - remnants of pulpal components, parts of odontoblasts, noticeable elongated dentinal tubules; b) instrumented area with a tree-bark model of smear layer which appears in both hand and rotary root canal instrumentation [9].

Slika 1. Fiziološki rastvor. a) neinstrumentisana površina - zaostale komponente pulpe, delovi odontoblasta, uočljivi uzdužno presečeni dentinski kanalići; b) instrumentisana površina sa tree-bark modelom razmaznog sloja koji se pojavljuje i kod ručne i kod mašinske obrade kanala korena [12].
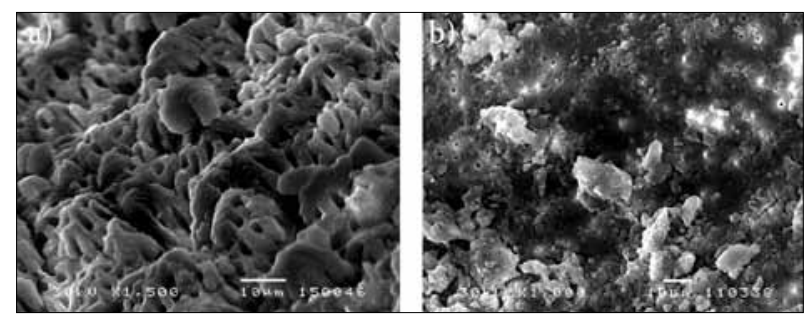

Figure 2. $\mathrm{NaOCl}$. a) uninstrumented area - dome-shaped calcospherites with a grainy, uneven surface; $b$ ) instrumented area smear layer covers dentin, with barely visible tubular orifices

Slika 2. $\mathrm{NaOCl}$. a) neinstrumentisana površina - kupolasti kalcisferiti sa sitno zrnastom, neravnom površinom; b) instrumentisana površina - razmazni sloj pokriva dentinsku površinu, jedva uočljivi otvori dentinskih kanalića
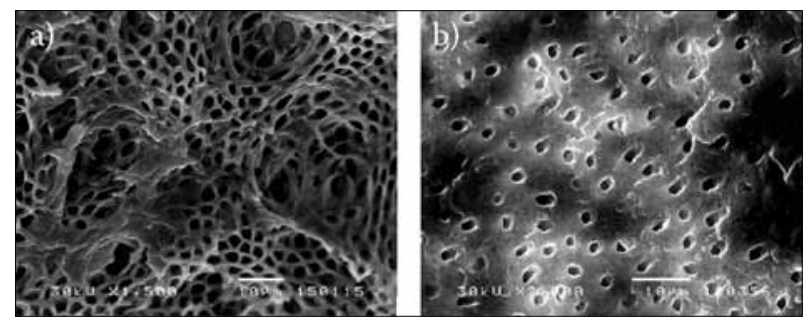

Figure 3. EDTA. a) uninstrumented area - groovy surface of dentin with no calcospherites; b) instrumented area - removed smear layer, but with presence of debris

Slika 3. EDTA. a) neinstrumentisana površina - talasasta površina dentina bez kalcisferita; b) instrumentisana površina - uklonjen razmazni sloj, ali prisutan debris
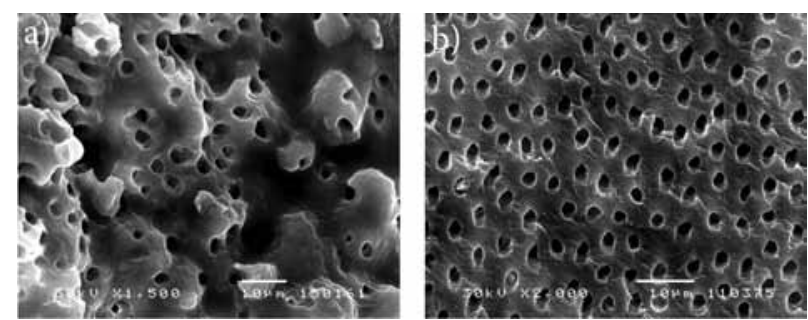

Figure 4. $\mathrm{NaOCl}+$ EDTA. a) uninstrumented area - a reduction in calcospherites, no organic debris; b) instrumented area - root canal wall with removed debris and smear layer

Slika 4. $\mathrm{NaOCl}$ + EDTA. a) neinstrumentisana površina - redukcija kalcisferita, nema organskog debrisa; b) instrumentisana površina - zid kanala korena sa uklonjenim debrisom i razmaznim slojem

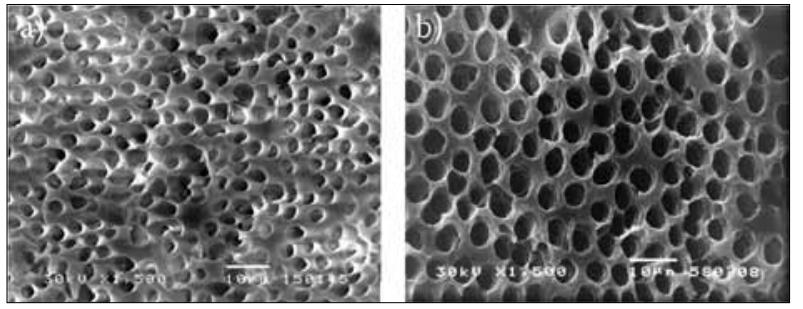

Figure 5. $\mathrm{NaOCl}+\mathrm{EDTA}+\mathrm{NaOCl}$. a) uninstrumented area - apronounced reduction in calcospherites with a funnel-like widening on dentinal tubules, no organic debris; b) instrumented area - root canal wall with removed debris and smear layer, but with intratubular dentin which has worn away. Dentin erosion in some areas connects two or more orifices of the dentin tubules.

Slika 5. $\mathrm{NaOCl}+$ EDTA $+\mathrm{NaOCl}$. a) neinstrumentisana površina - izrazita redukcija kalcisferita sa levkasto proširenim dentinskim kanalićima, odsutan organski debris; b) instrumentisana površina - zid kanala korena sa uklonjenim debrisom i razmaznim slojem, ali i sa istanjenim intratubularnim dentinom. Dentinska erozija na nekim mestima spaja dva ili više otvora dentinskih kanalića.

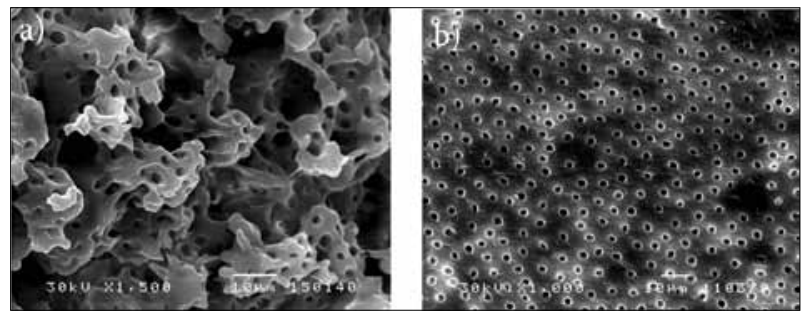

Figure 6. $\mathrm{NaOCl}+\mathrm{EDTA}+\mathrm{CHX}$. a) uninstrumented area-moderately reduced calcospherites, some of which have retained their dome-shaped form; b) instrumented area - root canal wall with removed debris and smear layer, no erosion of intratubular and peritubular dentin.

Slika 6. $\mathrm{NaOCl}+$ EDTA + CHX. a) neinstrumentisana površina umereno redukovni kalcisferiti, pojedini su zadržali kupolasti oblik; b) instrumentisana površina - zid kanala korena sa uklonjenim debrisom i razmaznim slojem, nema erozije intratubularnog i peritubularnog dentina.
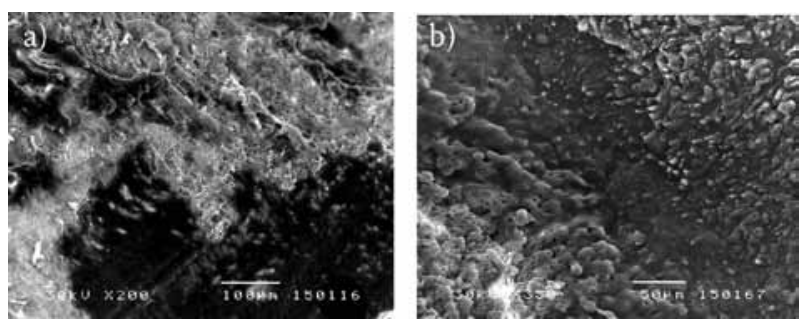

Figure 7. a) The darker areas on the micrography represent instrumented surfaces; b) An ultrastructural appearance of the uninstrumented root canal following irrigation using $\mathrm{NaOCl}$ solution, magnified at 350x. On dentin walls dome-shaped and ridge-shaped calcospherites are noted.

Slika 7. a) tamna polja na mikrografiji predstavljaju instrumentisane površine; b) ultrastrukturni izgled neinstrumentisanog kanala korena posle irigacije sa $\mathrm{NaOCl}$ na uvećanju 350x. Na dentinskim zidovima se uočavaju kupolasti i grebenasti kalcisferiti.

[20], instrument taper [21] or file alloy properties [22] add to impossibility to instrument all canal walls.

In the current study we assumed that uninstrumented surfaces in the main root canal actually exist, which is why biomechanical instrumentation was performed with the intention of leaving half of the root canal uninstrumented. On the other hand, instrumented areas of the root canal showed surfaces with expected morphology and more-less 
clean wall surfaces following certain irrigation regimens as reported in other studies [13-15]. In our study we analyzed only the coronal and middle third of the canal, while the apical third was excluded due to its complexity and possible presence of a smear layer even after irrigation that could influence the interpretation of obtained results.

Uninstrumented areas of the canal were difficult to notice prior to irrigation with $\mathrm{NaOCl}$ that removed organic debris and exposed conical and wedge-shaped calcospherites. Structures that were found on uninstrumented areas included pulpal tissue remnants, odontoblastic extensions, but no smear layer was found. In the current study 3\% $\mathrm{NaOCl}$ solution was used and completely removed organic debris. In studies where canals were irrigated with $0.5 \%$ $\mathrm{NaOCl}$ solution, dentin of uninstrumented areas was not completely cleaned of organic debris [23].

According to the findings of many studies, $\mathrm{NaOCl}$ irrigation is exceptionally important because it dissolves organic tissue very efficiently. Even though it has an inadequate surface tension and cannot reach narrow canals, $\mathrm{NaOCl}$ can effectively clean uninstrumented areas of the main canal that consist of predentin, necrotic pulpal tissue and a bacterial biofilm $[7,24]$.

Following irrigation regimens IV, V, and VI $(\mathrm{NaOCl}+\mathrm{EDTA} ; \mathrm{NaOCl}+\mathrm{EDTA}+\mathrm{NaOCl} ; \mathrm{NaOCl}$ + EDTA+CHX) uninstrumented surfaces showed more or less reduced calcospherites that was also confirmed in other studies. However, some studies have not found calcospherites after the same irrigation regimens $[11,18]$.

In the current study, following irrigation regimen $\mathrm{V}$ $(\mathrm{NaOCl}+\mathrm{EDTA}+\mathrm{NaOCl})$, erosion of intertubular and peritubular dentin occurred on both uninstrumented and instrumented surfaces. Most likely $\mathrm{NaOCl}$ was not able to prevent demineralizing effect of EDTA on peritubular and intertubular dentin due to its slow degradation [25]. In addition, there was an interaction between EDTA and $\mathrm{NaOCl}$ that manifested in sudden decrease in the amount of free chlorine causing loss of $\mathrm{NaOCl}$ activity and inability to dissolve soft tissue within the canal [26]. In our study no organic debris was noted after this irrigation regimen, but many authors do not recommend the use of $\mathrm{NaOCl}$ as the final irrigant (after EDTA) due to possible dentinal erosion $[25,27]$.

The literature reports interaction between irrigants that can be manifested as mutual inactivation, coloring of dentin or creation of harmful precipitation [28-30]. Therefore, flushing canals with sterile water between each irrigant is recommended, as well as drying the canal prior to introduction of a new irrigant $[26,29]$. In the current study, these recommendations were followed in order to prevent any unwanted interactions between the irrigants and obtain desired result [11].

Following irrigation regimen $\mathrm{VI}(\mathrm{NaOCl}+\mathrm{EDTA}+\mathrm{CHX})$ no dentinal erosion was noted. According to the literature, when EDTA and CHX come into contact EDTA anion is neutralized with CHX cation and there is no further reduction in dentin [30]. In addition, antimicrobial effect of CHX against Enterococcus faecalis and Candida albicans as well as its substantivity (prolonged effect) support its use as the final irrigant in endodontic treatment [24].

\section{CONCLUSION}

Taking into consideration limitations of all in vitro studies, the following can be concluded:

The morphology of uninstrumented areas of main root canal is similar to the morphology of those parts of the canal endodontic instruments cannot reach (narrowings, lateral canals, anastomosis, invagination of the root canal, etc.).

The presence of uninstrumented areas in the root canal during endodontic instrumentation is inevitable due to the complex morphology of the canals and indicates the importance of irrigants use during instrumentation.

Even though this was not the primary aim of this study, the most favorable effect of irrigation (including instrumented and uninstrumented areas of the canal) was noted following the irrigation regimen: $\mathrm{NaOCl}+\mathrm{EDTA}$, or even better using $\mathrm{NaOCl}+\mathrm{EDTA}+\mathrm{CHX}$ as the final irrigant.

\section{REFERENCES}

1. Rudde C). Cleaning and shaping root canal system. In: Cohen S, Burns RC, editors. Pathway of the pulp. 8th ed. St.Louis: Mosby; 2002. p. 231-91.

2. Violish DR, Chandler NP. The smear layer in endodontics - a review. Int Endod J. 2010; 43:2-15. [DOl: 10.1111/j.1365-2591.2009.01627.x] [PMID: 20002799]

3. Li KZ, Gao Y, Zhang R, Hu T, Guo B. The effect of a manual instrumentation technique on five types of premolar root canal geometry assessed by microcomputed tomography and three-dimensional reconstruction. BMC Med Imaging. 2011; 15:11-4. [DOI: 10.1186/14712342-11-14] [PMID: 21676233]

4. Markvart M, Darvann TA, Larsen P, Dalstra M, Kreiborg S, Bjorndal L. Micro-CT analyses of apical enlargement and molar root canal complexity. Int Endod J. 2012; 45:273-81. [DOI: 10.1111/j.13652591.2011.01972.x] [PMID: 22044111]

5. Elsherief SM, Zavet MK, Hamounda IM. Cone-beam computed tomography analysis of curved root canals after mechanical preparation with three nickel-titanium rotary instruments. J Biomed Res. 2013; 27:326-35. [DOl: 10.7555/JBR.27.20130008] [PMID: 23885273]

6. Zhao D, Shen Y, Peng B, Haapasalo M. Root canal preparation of mandibular molars with 3 nickel-titanium rotary instruments: a micro-computed tomographic study. J Endod. 2014; 40:1860-4. [DOI: 10.1016/j.joen.2014.06.023] [PMID: 25205262]

7. Haapasalo M, Shen Y, Qian W, Gao Y. Irrigation in endodontics. Dental Clin North Am. 2010; 54:291-312. [DOI: 10.1016/j. cden.2009.12.001] [PMID: 20433979]

8. Torabinejad M, Handysides R, Khademi AA, Bakland LK. Clinical implications of the smear layer in endodontics: a review. Oral Surg Oral Med Oral Pathol Oral Radiol Endod. 2002; 94:658-66. [DOl: 10.1067/ moe.2002.128962] [PMID: 12464887]

9. Silva PV, Guedes DF, Nakadi FV, Pecora JD, Cruz-Filho AM. Chitosan: a new solution for removal of smear layer after root canal instrumentation. Int Endod ]. 2013; 46:332-8. [DOI: 10.1111/j.13652591.2012.02119.x] [PMID: 22970844]

10. Peters OA. Current challenges and concepts in the preparation of root canal systems: a review. J Endod. 2004; 30:559-67. [DOl: 10.1097/01.DON.0000129039.59003.9D] [PMID: 15273636]

11. Braumgartner JC, Mader CL. A scanning electron microscopic evaluation of four root canal irrigation regimens. J Endod. 1987; 13:147-57. [DOI: 10.1016/S0099-2399(87)80132-2] [PMID: 3106553]

12. Prati C, Foschi F, Nucci C, Lucio, Montebugnoli L, Marchionni S. Appearance of the root canal walls after preparation with NiTi rotary instruments: A comparative SEM Investigation. Clinic Oral Invest. 2004; 8:102-10. [DOI: 10.1007/s00784-004-0253-8] [PMID: 14760541] 
13. Rodig T, Dollmann S, Konietschke F, Drebenstedt S, Hulsmann M. Effectiveness of different irrigant agitation techniques on debris and smear layer removal in curved root canals: a scanning electron microscopy study. J Endod. 2010; 36:1983-7. [DOI: 10.1016/j. joen.2010.08.056] [PMID: 21092817]

14. Akyuz Ekim SN, Erdemir A. Comparison of different irrigation activation techniques on smear layer removal: An in vitro study. Microsc Res Tech. 2015; 78:230-9. [DOI: 10.1002/jemt.22466] [PMID: 25582378]

15. Mendonca DH, Colucci V, Rached-Junior FJ, Miranda CE, Silva-Souza YT, Silva SR. Effects of various irrigation/aspiration protocols on cleaning of flattened root canals. Braz Oral Res. 2015; 29:1-9. [DOl: 10.1590/1807-3107BOR-2015.vol29.0082] [PMID: 26154369]

16. Peters OA, Schenberger K, Laib A. Effects of four Ni-Ti preparation techniques on root canal geometry assessed by micro computed tomography. Int Endod J. 2001; 34:221-30. [DOl: 10.1046/j.13652591.2001.00373.x] [PMID: 12193268]

17. Schafer E, Schlingemann R. Efficiency of rotary nickel titanium K3 instruments compared with stainless steel hand K-Flexofile. Part 2. Cleaning effectiveness and shaping ability in severely curved root canals of extracted teeth. Int Endod J. 2003; 36:208-17. [DOl: 10.1046/j.1365-2591.2003.00644.x] [PMID: 12657147]

18. Foschi F, Nucci C, Montebugnoli L, Marchionni S, Breschi L, Malagnino VA., Pratti C. SEM evaluation of canal wall dentine following use of Mtwo and ProTaper NiTi rotary instruments. Int Endod J. 2004; 37:832-9. [DOI: 10.1111/j.1365-2591.2004.00887.x] [PMID: 15548274]

19. de Oliveira MA, Venancio JF, Pereira AG, Raposo LH, Biffi JC. Critical instrumentation area: influence of root canal anatomy on the endodontic preparation. Braz Dent J. 2014; 25:232-6. [DOI: 10.1590/01036440201300013] [PMID: 25252259]

20. Wu MK, Wesselink PR. A primary observation on the preparation and obturation of oval canals. Int Endod J. 2001; 34:137-41. [DOl: 10.1046/j.1365-2591.2001.00361.x] [PMID: 11307262]

21. Elayouti A, Chu AL, Kimionis I, Klein C, Weiger R, Lost C. Efficacy of rotary instruments with greater taper in preparing oval root canals. Int Endod J. 2008; 41:1088-1092. [DOI: 10.1111/j.1365-2591.2008.01475.x] [PMID: 19133098]
22. Grande NM, Plotino G, Butti A, Messina F, Pameijer CH, Somma F. Cross-sectional analysis of root canals prepared with NiTi rotary instruments and stainless steel reciprocating files. Oral Surg Oral Med Oral Pathol Oral Radiol Endod. 2007; 103:120-126. [DOl: 10.1016/j. tripleo.2005.12.002] [PMID: 17178505]

23. Baumgartner JC, Cuenin PR. Efficacy of several concentrations of sodium hypochlorite for root canal irrigation. I Endod. 1992; 18:60512. [DOI: 10.1016/S0099/(06)81331-2] [PMID: 1298800]

24. Zehnder M. Root canal irrigants. J Endod. 2006; 32:389-98. [DOI: 10.1016/j.joen.2005.09.014] [PMID: 16631834]

25. Grande NM, Plotino G, Falanga A, Pomponi M, Somma F. Interaction between EDTA and sodium hypochlorite: a nuclear magnetic resonance analysis. J Endod. 2006; 32:460-464. [DOI: 10.1016/j. joen.2005.08.007] [PMID: 16631849]

26. Clarkson RM, Podlich HM, Moule AJ. Influence of ethylene diamine tetra acetic acid on the active chlorine content of sodium hypochlorite solutions when mixed in various proportions. J Endod. 2011; 37:538-543. [DOI: 10.1016/j.joen.2011.01.018] [PMID: 21419305]

27. Qian W, Shen Y, Haapasalo M. Quantitative analysis of the effect of irrigant solution sequences on dentin erosion. J Endod. 2011; 37:143741. [DOI: 10.1016/j.joen.2011.06.005] [PMID: 21924198]

28. Gasic J, Popovic J, Zivkovic S, Petrovic A, Barac R, Nikolić M. Ultrastructural analysis of the root canal walls after simultaneous irrigation of different sodium hypochlorite concentration and $0.2 \%$ chlorhexidine gluconate. Microsc Res Tech. 2012; 75:1099-103. [DOI: 10.1002/ jemt.22036] [PMID: 22419366]

29. Rossi-Fedele G, Dogramaci EJ, Guastalli AR, Steier L, de Figueiredo JA. Antagonistic interactions between sodium hypochlorite, chlorhexidine, EDTA, and citric acid. J Endod. 2012; 38:426-31. [DOI: 10.1016/j. joen.2012.01.006] [PMID: 22414823]

30. Rasimick BJ, Nekich M, Hladek M, Musikant BL, Deutsch AS. Interaction between hlorhexidine digluconate and EDTA. J Endod. 2008; 34:1521-23. [DOI: 10.1016/j.joen.2008.08.039] [PMID: 19026886] 


\title{
Ultrastrukturna analiza neinstrumentisanih površina u kanalu korena posle različitih irigacionih protokola
}

\author{
Radomir Barac ${ }^{1}$, Jelena Popović', Slavoljub Živković2, Aleksandar Mitić', Marija Nikolić', Jovanka Gašić1 \\ 'Odeljenje za bolesti zuba i endodonciju, Klinika za stomatologiju, Medicinski fakultet, Univerzitet u Nišu, Niš, Srbija; \\ ${ }^{2}$ Klinika za bolesti zuba i endodonciju, Stomatološki fakultet, Univerzitet u Beogradu, Beograd, Srbija
}

\begin{abstract}
KRATAK SADRŽAJ
Uvod Tokom endodontske terapije manje ili veće površine kanala korena zuba ostaju neinstrumentisane i mogu sadržavati bakterije, što može dovesti do neuspešnog ishoda. Cilj rada je bio da se skening-elekron-mikroskopskom (SEM) analizom proceni morfologija neistrumentisanih delova zidova kanala posle instrumentacije i primene različitih irigacionih protokola.

Materijal i metode rada Osamnaest jednokorenih ekstrahovanih zuba je podeljeno u šest grupa. Jedan zub iz svake grupe je predstavljao kontrolni uzorak. Eksperimentalni uzorci su preparisani do instrumenta veličine ISO40. Kod svakog zuba je instrumentisana samo jedna polovina kanala. Kontrolni uzorci su podvrgnuti samo irigacionim protokolima bez preparacije. Osim fiziološkog rastvora, $3 \%$ natrijum-hipohlorita i 15\% etilen-diamin-tetra-acetata, koji su primenjeni samostalno, eksperimentalni uzorci su irigirani i sa kombinacijom $\mathrm{NaOCl}$ i EDTA, kao i sa kombinacijom istih iriganasa, pri čemu je kao završni irigans korišćen ili $\mathrm{NaOCl}$ ili hlorheksidin. Korenovi su uzdužno presečeni i pripremljeni za SEM.

Rezultati Posle irigacije sa fiziološkim rastvorom u neinstrumentisanim delovima kanala uočen je dentin pokriven debrisom, posle irigacije sa $\mathrm{NaOCl}$ dentin sa različitim oblicima kalcisferita. Posle irigacije sa EDTA uočena je talasasta površina dentinskog zida sa otvorenim tubulima bez razmaznog sloja. Irigacija kombinacijom $\mathrm{NaOCl}$ i EDTA je pokazala ostatke kalcisferita i otvorene, blago proširene dentinske tubule. Završno ispiranje sa $\mathrm{NaOCl}$ na neinstrumentisanim delovima dentina pokazuje proširene dentinske tubule i eroziju dentina, a završno ispiranje sa $\mathrm{CHX}$ čist dentin i otvorene dentinske tubule bez razmaznog sloja.

Zaključak Sa morfološkog aspekta, najpovoljniji efekat irigacije ( $\mathrm{i}$ kod instrumentisanih $\mathrm{i}$ kod neinstrumentisanih delova kanala) ustanovljen je posle irigacionih protokola sa: $\mathrm{NaOCl}$ i EDTA i $\mathrm{NaOCl}$, EDTA i hlorheksidinom kao završnim irigansom.

Ključne reči: preparacija kanala; neinstrumentisane površine kanala; irigacija kanala; SEM
\end{abstract}

\section{UVOD}

Jedan od osnovnih preduslova za uspeh endodontskog lečenja je adekvatna preparacija kanala korena zuba. Međutim, instrumentaciju i irigaciju je uglavnom teško realizovati zbog vrlo specifične i kompleksne kanalne morfologije, ali i ograničenog efekta instrumenata u nepristupačnom i ograničenom prostoru [1].

Morfološke varijacije kanalnog sistema i nemogućnost endodontskog instrumenta da dopre do svih delova zidova kanala korena potpuno čišćenje kanala čine praktično nemogućim $[1,2]$. Nekoliko studija je primenom mikrokompjuterizovane tomografije potvrdilo da tokom preparacije kanala deo zidova ostaje potpuno neobrađen [3-6]. Na ovim nepristupačnim površinama zidova kanala mogu se zadržavati bakterije i time ugroziti i kompromitovati endodontsko lečenje [7].

Osim toga, i prisustvo razmaznog sloja i debrisa kao posledica instrumentacije i sečenja dentina predstavlja značajan klinički problem $[2,8]$. Ovaj sloj često sadrži bakterije i blokira dentinske tubule, čime značajno umanjuje efekat sredstava za irigaciju, odnosno značajno utiče na kvalitet opturacije i ishod endodontskog lečenja $[8,9]$.

Zbog ograničene efikasnosti endodontskih instrumenata u čišćenju kanala neophodno je tokom i posle instrumentacije obavezno koristiti i odgovarajuća hemijska sredstva. Njihova uloga je u eliminaciji i redukciji zaostalih mikroorganizama, odnosno u efikasnom čišćenju kanalnog sistema, kao i rastvaranju i uklanjanju razmaznog sloja [8-10].

Iako ne postoji opšta saglasnost oko uklanjanja razmaznog sloja neposredno pre opturacije, najveći broj endodonata je saglasan da, ukoliko se on ne ukloni, vremenom može doći do njegove dezintegracije i povećanog kruničnog mikropropuštanja, usled slabijeg kvaliteta veze materijala za opturaciju sa zidovima kanala korena $[9,10]$.
Cilj ovog rada je bio da se SEM analizom proceni morfologija neinstrumentisanih delova zidova kanala korena posle mehaničke instrumentacije i primene različitih protokola za irigaciju.

\section{MATERIJAL I METODE RADA}

Kao materijal u ovom istaživanju korišćeno je 18 sveže ekstrahovanih intaktnih jednokorenih humanih zuba bez vidljivih oštećenja (karijes korena, pukotine, unutrašnje ili spoljašnje resorpcije itd.). U odnosu na irigacioni protokol, svi zubi su podeljeni u šest grupa, pri čemu je po jedan zub iz svake predstavljao kontrolu. Uzorci zuba su čuvani osam časova u $0,5 \%$ $\mathrm{NaOCl}$ da bi se lakše uklonili ostaci organskog tkiva. Potom su čišćeni, ispirani tekućom vodom, potopljeni u fiziološki rastvor i čuvani u frižideru do početka eksperimenta.

Pre instrumentacije kanala pažljivo su dijamantskim diskom napravljeni žlebovi po uzdužnoj osovini korena (vestibularno i oralno), ali bez kontakta sa kanalom, kako bi se kasnije olakšalo razdvajanje polovina. Krunice zuba su uklonjene, a debris nastao prilikom presecanja je ispran u tekućoj vodi.

Posle uklanjanja sadržaja kanala pulp ekstirpatorima, po jedan zub (dva kontrolna uzorka) iz svake grupe je podvrgnut samo irigacionim protokolima bez prethodne preparacije.

Na korenovima ostalih zuba izvršena je provera prohodnosti, a radna dužina preparacije je određivana skraćivanjem za 1 mm od dužine endodontske igle kada vrh igle dosegne apeksni otvor. Apeks svakog uzorka zuba je potom zapečaćen kuglicom roze voska.

Korenovi eksprimentalnih zuba su preparisani step back tehnikom instrumentima do dijametra ISO40 (NiTi I-FLEX, IMD, USA). Posebno je obeležena i instrumentisana samo jedna polovina kanala korena (vestibularna ili oralna) [11]. Pri pre- 
paraciji se vodilo računa da endodontski instrumenti ne dođu u kontakt sa drugim delom kanala koji je predstavljao „neinstrumentisanu“ polovinu kanala korena. Kontroloni uzorak iz svake grupe je služio za poređenje neinstrumentisanih delova kanala sa neinstrumentisanim kanalom korena posle identičnih irigacionih protokola.

Količina irigansa koja je korišćena sa svaki irigacioni protokol bila je identična i pažljivo kontrolisana, kao i ukupno vreme hemomehaničke obrade svakog kanala (10 min).

U eksperimentu je korišćeno šest protokola ispiranja: (I) samo fiziološki rastvor; (II) samo 3\% natrijum-hipohlorit (NaOCl-Parcan, Septodont); (III) samo 15\% etilen-diamin-tetraacetat (EDTA - Largal Ultra, Septodont); (IV) kombinacija 3\% $\mathrm{NaOCl}+15 \%$ EDTA; (V) kombinacija 3\% NaOCl+15\% EDTA i 3\% NaOCl kao završni irigans; (VI) kombinacija 3\% NaOCl+15\% EDTA i 2\% hlorheksidin (R4, Septodont) kao završni irigans. (Tabela 1).

Uz blagi pritisak, uzorci su pomoću špatule podeljeni na polovine (tako je dobijeno 36 uzoraka) i stavljeni u otvorene Petrijeve šolje da bi se sušili na sobnoj temperaturi. Posle 24 časa uzorci su pričvršćeni za cilindrične nosače sredstvom za fiksiranje (Dotite paint xc 12 Carbon JEOL, Tokyo, Japan), naparavani tankim slojem zlata po površini (u uređaju JFC 1100E Ion Sputter JEOL) i analizirani skening elektronskim mikroskopom (SEM, JEOL-JSM-5300).

\section{REZULTATI}

Dobijeni rezultati SEM analize su pokazali da je u neinstrumentisanim delovima kanala posle irigacije sa fiziološkim rastvorom uočen dentin pokriven pulpnim debrisom, posle irigacije sa $3 \%$ rastvorom $\mathrm{NaOCl}$ uočen dentin sa različitim oblicima kalcisferita, a posle irigacije sa EDTA uočena je talasasta površina dentinskog zida i otvoreni tubuli bez razmaznog sloja. Kada je korišćena kombinacija $\mathrm{NaOCl}$ i EDTA, uočeni su ostaci kalcisferita i otvoreni i blago prošireni dentinski tubuli. Kada je kao završni irigans korišćen $\mathrm{NaOCl}$ na neinstrumentisanim delovima dentina, uočeni su uvećani dentinski tubuli i erozija dentina, a kada je kao završni irigans korišćen CHX - čist dentin i otvoreni dentinski tubuli bez razmaznog sloja.

Rezultati SEM neinstrumentisanih i instrumentisanih površina su prikazani u tabeli 2 i na mikrografijama od 1 do 10 .

Morfologija zidova neinstrumentisanih delova preparisanog kanala korena nije pokazivala razlike u odnosu na morfologiju neinstrumentisanih kanala (kontrolne uzorke) posle svih irigacionih protokola.

\section{DISKUSIJA}

U ovom istraživanju je bio cilj da se SEM-om ispita morfologija neinstrumentisanih delova zidova kanala korena tokom obrade kanala. Nekoliko studija je metodom mikrokompjuterizovane tomografije ustanovilo prisustvo neinstrumentisanih polja $\mathrm{u}$ glavnom korenskom kanalu izračunavanjem površine koja ostaje netaknuta tokom tretmana (meren je volumen kanala pre i posle instrumentacije, rastojanje između površine kanala pre i posle preparacije $u \mu \mathrm{m}$, površina određenog polja, debljina kanala, koničnost itd.) [3-6]. Za razliku od toga, SEM analizom je omo- gućena bolja vizuelizacija kvaliteta čišćenja zidova kanala korena, pokrivenost dentinskih tubula razmaznim slojem, kao i kompletna morfologija dentina na ultrastrukturnom nivou [13-15].

Ovo istraživanje je koristilo kao kontrolne uzorke neinstrumentisane zidove kanala koji su predstavljali model ultrastrukture dentinskog zida posle određenih irigacionih protokola. $\mathrm{Na}$ ovaj način je bilo moguće porediti morfologiju neinstrumentisanih kanala sa neinstrumentisanim površinama preparisanih kanala. Prema Petersu i sar., u toku procesa širenja i oblikovanja, bilo mašinskim ili ručnim instrumentima, oko $35 \%$ površine kanala ostaje neinstrumentisano [16]. Takođe, i druge studije potvrđuju prisustvo neinstrumentisanih polja, naročito u apeksnoj trećini u kojoj nepravilnosti na zidovima kanala (žlebovi i udubljenja) sprečavaju kontakt između zida i instrumenata [17, 18]. Endodontski instrumenti su uglavnom dizajnirani tako da se uklope u konusnu konfiguraciju korena, što ovalne ili spljoštene kanale ostavlja sa nepreparisanim poljima [16]. Drugi autori postojanje neinstrumentisanih regija opravdavaju pre svega kompleksnom kanalnom morfologijom [19], ograničenošću instrumentacionih tehnika [20], koničnošću instrumenata [21] ili osobinama legure od koje su izrađeni instrumenti [22].

U ovom istraživanju se pošlo od pretpostavke da neinstrumentisane površine u glavnom korenskom kanalu zaista postoje, zbog čega je mehanička instrumentacija urađena sa namerom da se polovina zida korenskog kanala ostavi bez mehaničke obrade. S druge strane, instrumentisani delovi u kanalu korena su pokazali površinu sa očekivanom morfologijom manje ili više čistih zidova posle određenih irigacionih protokola, kako je objavljeno i u drugim studijama [13-15]. U ovom istraživanju su analizirane samo cervikalna i srednja trećina kanala, dok je izostavljena apeksna trećina, koja bi zbog svoje kompleksnosti i mogućeg prisustva razmaznog sloja i posle irigacionih protokola mogla uticati na tumačenje dobijenih rezultata.

Neinstrumentisane oblasti zidova kanala je bilo teško uočiti pre irigacije sa $\mathrm{NaOCl}$, koji je uklonio organske ostatke i prikazao kupolaste ili grebenaste kalcisferite. Na neinstrumentisanim površinama su nađene strukture koje su zbog svoje pozicije ukazivale na ostatke pulpnog tkiva, ili čak delove odontoblastičnih produžetaka, ali na njima nije bilo razmaznog sloja. U ovom istraživanju je korišćen $3 \% \mathrm{NaOCl}$, koji je kompletno uklonio organske ostatke. U studijama gde je kanal korena irigiran sa $0,5 \% \mathrm{NaOCl}$, površine dentinskog zida neinstrumentisanih oblasti nisu bile u potpunosti očišćene od organskih ostataka [23].

Prema nalazima većine studija, korišćenje $\mathrm{NaOCl}$ tokom instrumentacije je izuzetno važno jer ovaj irigans dobro rastvara organsko tkivo u kanalnom sistemu korena. Iako ima neadekvatan površinski napon i ne može da prodre do uskih i akcesornih kanala, $\mathrm{NaOCl}$ efikasno „čisti“ neistrumentisane delove glavnog kanala, koji se sastoje od predentina, nekrotičnog pulpnog tkiva i bakterijskog biofilma [7, 24].

Posle irigacionih protokola IV ( $\mathrm{NaOCl}$ i EDTA), $\mathrm{V}(\mathrm{NaOCl}$ + EDTA i NaOCl kao završni irigans) i VI ( $\mathrm{NaOCl}+$ EDTA i CHX kao završni irigans), na neinstrumentisanim površinama nađeni su manje ili više redukovani kalcisferiti, što je u skladu sa drugim istraživanjima, iako u nekim studijama posle identičnih protokola irigacije kalcisferiti nisu ni uočeni $[11,18]$.

$\mathrm{U}$ ovom istraživanju, posle irigacionog protokola $\mathrm{V}$, gde je kao završni irigans korišćen $\mathrm{NaOCl}$, došlo je do erozije intertubularnog i peritubularnog dentina i kod neinstrumentisanih i kod instrumentisanih polja. Ovo se može objasniti time što 
$\mathrm{NaOCl}$ nije mogao da spreči demineralizujuće dejstvo EDTA na peritubularni i intertubularni dentin jer dovodi do veoma spore degradacije ovog helatora [25]. Pored toga, postoji interakcija između EDTA i NaOCl, koja se ogleda u naglom smanjenju količine slobodnog hlora odmah pri kontaktu ovih iriganasa, što može da ima za posledicu gubitak aktivnosti $\mathrm{NaOCl}$ i nemogućnost rastvaranja mekog tkiva unutar kanala [26]. U ovom istraživanju nije primećen ni organski debris posle primene ovog protokola, ali mnogi autori ne preporučuju $\mathrm{NaOCl}$ kao finalni irigans (posle EDTA) zbog moguće erozije dentina [25, 27].

Literaturni podaci ukazuju i na postojanje interakcije između iriganasa, koje se mogu ispoljiti međusobnom inaktivacijom, prebojavanjem dentina ili stvaranjem štetnih precipitata [2830], zbog čega se preporučuje ispiranje kanala sa destilovanom (sterilnom) vodom između svakog irigansa i sušenje kanala pre uvođenja novog rastvora za irigaciju $[26,29,30]$. U protokolu ovog istraživanja su uvažene ove preporuke, kako bi se sprečile neželjene interakcije između iriganasa i pritom dobio adekvatan rezultat [11].

Posle irigacionog protokola VI $(\mathrm{NaOCl}+$ EDTA i CHX kao završni irigans) nije uočena erozija dentina. Prema podacima iz literature, pri kontaktu EDTA i CHX dolazi do neutralizacije anjonskog EDTA pomoću katjonskog CHX, zbog čega nema dalje redukcije dentina [30]. Pored toga, antimikrobni efekat
CHX (enteroccocus faecalis i Candida albicans), kao i osobina supstantivnosti ovog irigansa (protrahirani efekat), opravdavaju njegovu upotrebu kao završnog irigansa u endodontskom tretmanu [24].

\section{ZAKLJUČAK}

Uprkos ograničenjima karakteristišnim za sva in vitro istraživanja, na osnovu dobijenih rezultata može se zaključiti sledeće:

- Morfologija neinstrumentisanih delova glavnog korenskog kanala je slična morfologiji onih delova kanala do kojih endodontski instrumenti ne mogu dopreti (suženja, bočni kanali, anastomoze, invaginacije zidova korena itd.).

- Prisustvo neinstrumentisanih površina kanala korena tokom endodontske instrumentacije je neizbežno zbog kompleksne morfologije kanala i ukazuje na važnost adekvatne primene hemijskih sredstava i dezinfekcije svih oblasti kanalnog sistema.

- Iako to nije bio primarni cilj istraživanja, najpovoljniji efekat irigacije (i kod instrumentisanih i kod neinstrumentisanih delova kanala) uočen je posle primene irigacionih protokola sa: $\mathrm{NaOCl}$ i EDTA, odnosno $\mathrm{NaOCl}$, EDTA i CHX kao završnim irigansom. 